\title{
Effect of Seed Priming and Foliar Spraying of PGRs on Morpho- Physiology, Growth and Yield in Green gram (Vigna radiata L.)
}

\author{
R.S. Bhadane ${ }^{1}$, K.R. Prajapati ${ }^{2}$, K.C. Ombase ${ }^{3}$, D.B. Patel ${ }^{4}$
}

10.18805/LR-4434

\begin{abstract}
Background: Pre-sowing seed priming and foliar spraying with Plant Growth Regulators is an easy, low cost and low risk technique and also an alternative approach recently used to mitigate the effect of abiotic stresses in agricultural production.

Methods: Seeds of Mung bean var. GAM- 5 were primed and also foliar spraying at $30 \mathrm{DAS}$ with $\mathrm{CaCl}_{2} 2 \%$ and $1 \%$, Cycocel 500 , 1000 ppm, NAA 25, 50 ppm during summer season of 2015-16 and 2016-17.

Result: The results indicated a significant improvement in morpho-physiological traits, growth parameters, biochemical constituents and thereby yield due to the application of PGRs. Seed priming with $2 \% \mathrm{CaCl}_{2}$ followed by $1 \%$ foliar spraying at $30 \mathrm{DAS}\left(\mathrm{T}_{11}\right.$ ) significantly improved most of morpho-physiological parameters viz., plant height, number of branches per plant, days to $50 \%$ flowering, maturity, leaf area, chlorophyll content, seed protein content, number of pods per plant, number of seeds per pod, test weight, pod length, yield per plant, yield per hectare, harvest index in green gram followed by the seed priming with Cycocel 1000 ppm followed by foliar spraying at 30 DAS $\left(T_{13}\right)$ and seed priming with NAA 50 ppm followed by foliar spraying at 30 DAS $\left(T_{15}\right)$. The treatment $T_{11}$ was more efficient.
\end{abstract}

Key words: $\mathrm{CaCl}_{2}$, Cycocel, Chlorophyll, Foliar spray, Mung bean, NAA, Seed priming, SPAD.

\section{INTRODUCTION}

Mung bean (Vigna radiata L.) is an important pulse crop having high nutritive value, suitable for dry land farming and predominantly used as an intercrop with other crops. It contains about 25 per cent protein along with amino acids such as arginine, histidine, lysine and tryptophane etc. It is also considered as a cheap source of protein and other minerals. It has high digestibility and palatability (Vikram et al., 2019). It is a very good catch crop in summer and can be grown very well in this season. Mung bean is a short duration, low input requiring crop that matures in 65 to 80 days, photo and thermo-insensitive in nature. However, the productivity of mung bean is low.

Efforts made to maximize yield, is largely hampered by adverse effect of abiotic stress such as salinity and drought. These effects cause a huge loss due to low yield and failure of the crop to establish in some cases. Pre-sowing seed priming treatment is simple technique and an alternative approach recently used to overcome the effect of abiotic stresses in agricultural production. It is found to be efficient in improving seed emergence and growth of crops (Sankar Ganesh et al., 2013). It was reported clearly that the hardening treatment enhance seeds vigour by protecting structure of the plasma membrane against injury during stress (Bewley and Black, 1982; JunMin et al., 2000). It is a well established fact that, pre-soaking seeds with optimal concentration of phytohormones enhance their germination, dry matter accumulation, partitioning and yield of some crop species under condition of environmental stress by increasing nutrient reserves through increased physiological activities and root proliferation (Bozeuk, 1981).
'Oilseeds Research Station, Mahatma Phule Agricultural University, Jalgaon-425 001, Maharashtra, India.

${ }^{2}$ Vanbandhu Krishi Polytechnic School, S.K. Nagar Agriculture University, Amirgadh-385 130, Gujarat, India.

${ }^{3}$ Zonal Agricultural Research Station, Mahatma Phule Agricultural University, Solapur, Maharashtra, India.

${ }^{4}$ Dept. of Plant and Physiology, B. A. College of Agriculture, AAU, Anand-388 110, Gujarat, India.

Corresponding Author: R.S. Bhadane, Oilseeds Research Station, Mahatma Phule Agricultural University, Jalgaon-425 001, Maharashtra, India. Email: bhadaners@rediffmail.com

How to cite this article: Bhadane, R.S., Prajapati, K.R., Ombase, K.C. and Patel, D.B. (2020). Effect of Seed Priming and Foliar Spraying of Pgrs on Morpho-Physiology, Growth and Yield in Green gram (Vigna radiata L.). Legume Research. 10.18805/LR-4434

Submitted: 02-06-2020 Accepted: 13-10-2020 Online: 29-12-2020

Considering the constraints in the production potential of mung bean it is worthwhile to study the influence of different seed hardening and foliar spraying treatments on the production potential of mung bean. It is also of utmost importance to understand the physiological basis of yield attributing characters, partitioning in various plant parts and thereby yield variation due to seed hardening and foliar spraying of various growth regulators and chemicals. The pre-requisite for higher yield is related with the ability of genotype to produce high amount of total dry matter. Patil et al., (2007) reported that the manner in which the net dry matter is produced and distributed among the different parts of plant will determine the economic yield. The present study was therefore, undertaken to assess the morpho- 
physiological, growth and yield attributing characters in relation to yield in green gram.

\section{MATERIALS AND METHODS}

The present work was carried out at Agronomy farm, Anand Agricultural University, Anand to study the effect of seed hardening, foliar spraying and their combined effect on morpho-physiology, growth and yield in green gram (Vigna radiata L.) during summer season of 2015-16 and 2016-17. The trial was laid out in a randomized block design with three replications and sixteen treatment combinations including five seed hardening treatments, five foliar spraying treatments, five seed hardening treatments with foliar spraying and one absolute control treatment. Seeds of mung bean var. GAM5 were imposed with the following seed treatments.

The different solutions of plant growth regulators (PGRs) viz., $\mathrm{CaCl}_{2}$ 2\%, Cycocel 500, 1000 ppm and NAA 25, 50 ppm were prepared for seed hardening. PGRs treatments were given to sufficient quantity of seeds of Mung bean cv. GAM-5 for hardening, seeds were soaked in above prepared various solutions of double the volume of seed for three hours. This will ensure that seeds remained immersed in the solution, so as to avoid precocious germination during the treatment period. Hardening was given in flasks under room temperature. The seeds were then removed from respective solutions and kept overnight in shade for drying to attain the seeds to its original moisture level. The seeds were ready for sowing in field on next day.

The different solutions with their different concentrations were used in this experiment for foliar spraying at field level. The spraying solutions of $\mathrm{CaCl}_{2} 1 \%$, Cycocel 500, 1000 ppm and NAA 25, 50 ppm were prepared. The spraying was carried out as per treatments during the morning time or before noon at 30 days after sowing (DAS) in respective gross plot of each replication using knapsack sprayer.

\section{Morpho-physiological and growth parameters}

Plant height, number of branches per plant, number of nodes per plant, days to $50 \%$ flowering, days to maturity were recorded by non destructive method from each replication and treatment and the average values were calculated.

\section{Leaf Area $\left(\mathrm{cm}^{2}\right.$ plant $\left.{ }^{-1}\right)$}

Leaf area per plant was taken at harvest with the help of Leaf area meter (BIOVIS Company Model- 3100) at Regional Research Station, AAU, Anand. Five plants were randomly selected from all replications and clipped and recorded.

\section{Estimation of Total Leaf Chlorophyll Content}

Total chlorophyll content was estimated by the SPAD (soil plant analytical development) meter in which randomly three leaves were selected from lower, middle and upper portion at harvest. Before the measurement, instrument is calibrated - transmission is measured with no leaf inside. Thus, when a leaf is clamped by the meter, a certain portion of red light is absorbed and the meter can calculate a relative value (in SPAD), showing how green the leaf is. Basically, SPAD value correlates with actual chlorophyll content in the leaf, but measurements have to be taken at many points of the same leaf to be representative and calibration is to be performed for every plant species or cultivar to know the exact relationship between SPAD values and chlorophyll contents per unit area.

\section{Measurement of Seed Protein Content (\%)}

The protein content was determined by Micro-Kjeldhal method (AOAC, 1990). The method consists of heating a substance with sulphuric acid, which decomposes the organic substance by oxidation to liberate the reduced nitrogen as ammonium sulphate. In this step potassium sulphate was added to increase the boiling point of the medium (from $337^{\circ} \mathrm{C}$ to $373^{\circ} \mathrm{C}$ ). Chemical decomposition of the sample was completed when the initially very darkcoloured medium has become clear and colourless. The solution was then distilled with a small quantity of sodium hydroxide, which converts the ammonium salt to ammonia. The amount of ammonia present and thus the amount of nitrogen present in the sample, was determined by back titration. The end of the condenser was dipped into a solution of boric acid. The ammonia reacts with the acid and the remainder of the acid was then titrated with a sodium carbonate solution by way of a methyl orange $\mathrm{pH}$ indicator. Protein $(\%)=\mathrm{N}(\%) \times 6.25$

\section{Yield and yield components}

Tagged plants used for recording morphological observations were harvested at physiological maturity and were used for recording the yield and yield components viz., number of pods per plant, length of pod $(\mathrm{cm})$, number of seeds per pod, 1000 seed weight (Test weight) (g), seed yield per plant $\left(\mathrm{g}\right.$ plant $\left.^{-1}\right)$, seed yield per hectare $\left(\mathrm{Kg} \mathrm{ha}^{-1}\right)$ and harvest index (\%).

\section{RESULTS AND DISCUSSION \\ Plant height}

Table 1 represents that at harvest, plant height was maximum in the treatment of $\mathrm{CaCl}_{2} 2 \%$ seed hardening $+1 \%$ foliar spraying at $30 \mathrm{DAS}\left(\mathrm{T}_{11}\right)(37.00,40.67$ and $38.83 \mathrm{~cm})$ and remained at par with NAA $50 \mathrm{mg} / \mathrm{L}$ seed hardening + spraying at 30 DAS $\left(T_{15}\right)(35.67,39.33$ and $37.50 \mathrm{~cm})$, NAA $25 \mathrm{mg} / \mathrm{L}$ seed hardening + spraying at 30 DAS $\left(T_{14}\right)(34.67$, 37.50 and $36.08 \mathrm{~cm}$ ) and $\mathrm{CaCl}_{2} 1 \%$ spraying at 30 DAS $\left(\mathrm{T}_{6}\right)(33.67,37.00$ and $35.33 \mathrm{~cm})$. While Cycocel $1000 \mathrm{mg} /$ $\mathrm{L}$ spraying at 30 DAS $\left(\mathrm{T}_{8}\right)$ recorded significantly less plant height $(23.67,26.00$ and $24.83 \mathrm{~cm}$ ) during the year 2016, 2017 and pooled basis, respectively.

Plant height was increased due to treatments of $\mathrm{CaCl}_{2}$ and NAA, while decreased due to Cycocel at harvest in green gram. The decrease in plant height with cycocel may be attributed to anti-gibberellic activity of Cycocel mainly by blocking certain steps of gibberellin biosynthesis so that gibberellin is not made available for participation in plant growth (Jain, 2013). The mechanism of reduction of plant 


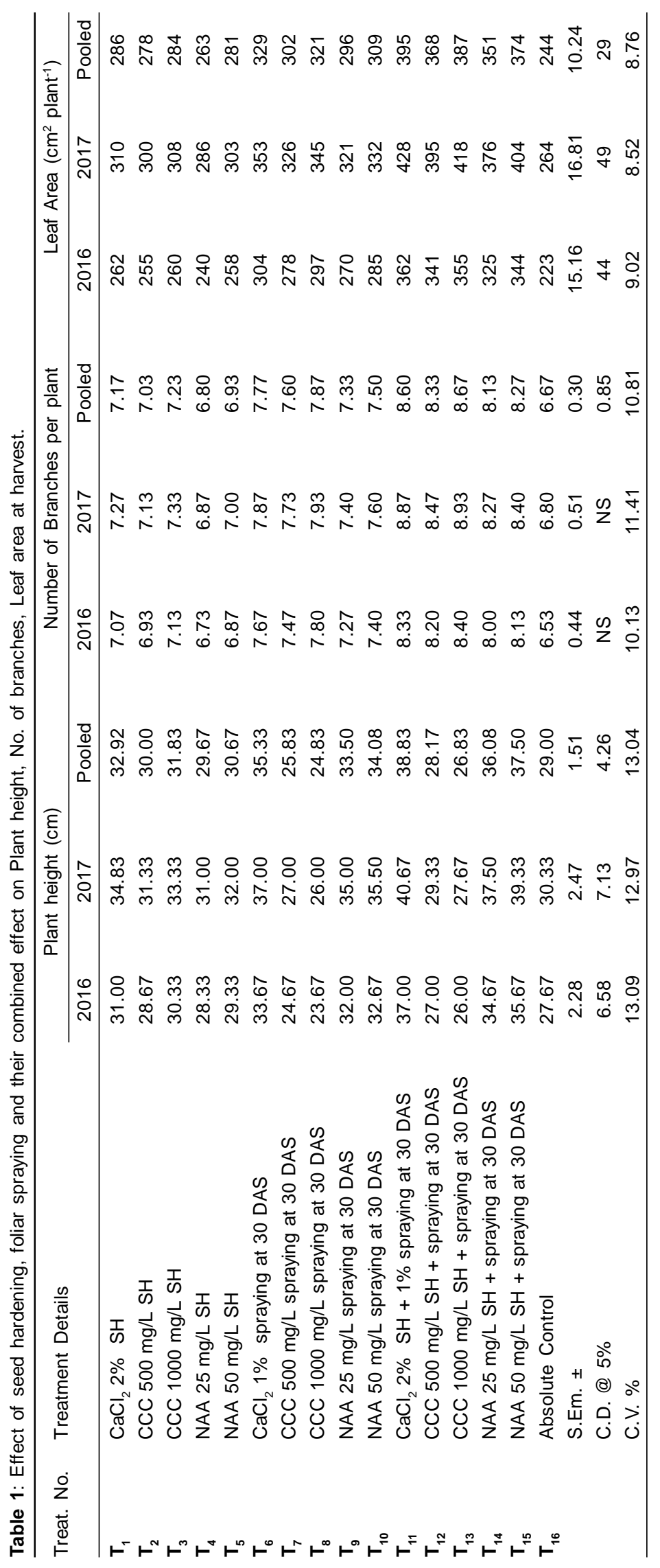


height by spraying with Cycocel also appears due to reduced cell size and cell wall thickening (Ginzo et al., 1977). Similarly, Dighe et al. (1983) also observed that 500 ppm cycocel significantly reduced the plant height in wheat.

It was observed that NAA showed a positive effect on plant height. The application of auxin in plant has a role in the stimulation of RNA and protein synthesis and greater enhancement in photosynthesis rate, increased in cell elongation as well as cell division and cell wall plasticity, which ultimately showed the enhancement in various growth parameters. The above finding were in agreement with the results reported by Ananthi and Mallika (2014) in green gram, Sunil Jadhav (2016) and Kinjal (2017) in black gram, Upadhyay et al. (2016) in soybean, Pothalkar (2007) in pigeon pea, Amarjeet Singh (2014) in turmeric, Sujatha et al. (2017) in chickpea.

\section{Number of branches}

At harvest, the number of branches per plant found statistically non significant during both the years. However, in pooled mean basis the treatment Cycocel $1000 \mathrm{mg} / \mathrm{L}$ seed hardening + spraying at 30 DAS $\left(T_{13}\right)$ recorded significantly higher (8.67) than untreated absolute control with minimum number of branches per plant (6.67).

The reduction in plant height due to growth retardants is mainly seems to have released the apical dominance and diversion of the plant metabolites from vertical growth to horizontal growth and thereby more number of branches per plant. These results are in conformity with the findings of Avijit Sen (1983) in wheat, Arjun Sharma et al. (2003) in pigeon pea, Manjunath and Dhanoji (2011) and Sujatha (2014) in chickpea.

\section{Leaf area}

Leaf area per plant gradually decreased towards harvesting stage in green gram. The data reported in Table 1 indicated that the treatment $\mathrm{CaCl}_{2} 2 \%$ seed hardening $+1 \%$ spraying at 30 DAS $\left(T_{11}\right)$ registered higher values of leaf area (362, 428 and $395 \mathrm{~cm}^{2}$ ) over all other treatments. It was followed by $\mathrm{T}_{13}\left(355,418\right.$ and $\left.387 \mathrm{~cm}^{2}\right), \mathrm{T}_{15}\left(344,404\right.$ and $\left.374 \mathrm{~cm}^{2}\right)$ and $T_{12}\left(341,395\right.$ and $\left.368 \mathrm{~cm}^{2}\right)$ during 2016, 2017 and in pooled analysis, respectively. Whereas, the treatment absolute control $\left(T_{16}\right)$ recorded significantly lower value of leaf area per plant (223, 264 and $244 \mathrm{~cm}^{2}$, respectively).

The increased in leaf area by seed hardening and foliar spraying with $\mathrm{CaCl}_{2}$ and NAA might be due to increase in cell division, cell enlargement as well as induce more extensive and denser network of veins and ribs and there by increased foliar leaf area. These results are conformity with the finding of Thirumalaiswamy and Rao (1977) in pearl millet, Ginzo et al. (1977) and Josana (2015) in chick pea, Shinde and Jadhav (1995) in cowpea, Pothalkar (2007) in pigeon pea, Prakash et al. (2013) in rice and Kinjal (2017) in black gram.

\section{Days to $50 \%$ flowering}

The data indicated in Table 2 showed non significant differences due to various treatments in both the years but in pooled basis differences were significant. In pooled analysis, the treatment $T_{11}$ (36.67) significantly taken minimum days to 50 per cent flowering followed by the treatments $\mathrm{T}_{13}(37.00), \mathrm{T}_{15}(37.17), \mathrm{T}_{12}$ (37.50) and $\mathrm{T}_{14}$ (37.83). While untreated absolute control $\left(T_{16}\right)$ recorded significantly maximum number of days $(42.00)$ to 50 per cent flowering. This might be due to early and faster emergence. Flower initiation is an important phonological development stage which determines the plant productivity.

It is inferred that, both the phenological stages viz., flower initiation and pod initiation were early due to seed hardening followed by the use of plant growth regulator's spray. Similar reports have been also made by Garai and Datta (2003) in green gram and Varma et al., (2004) in pigeon pea. The results in present investigation showed that minimum days taken for 50 per cent flowering in combined effect of seed hardening + foliar spraying followed by only foliar spraying and then only seed hardening treatments. In general, combined effect of seed hardening and foliar spraying was more effective in early flowering as compared to their individual effect.

\section{Days to maturity}

The data indicated non significant differences due to various treatments during both the years but in pooled analysis differences were significant. The treatment $T_{11}$ (73.17) taken minimum days to maturity followed by the treatments $T_{13}$ (73.50), $\mathrm{T}_{15}$ (73.83), $\mathrm{T}_{12}$ (74.33) and $\mathrm{T}_{14}$ (74.67). The untreated absolute control $\left(T_{16}\right)(79.00)$ taken significantly maximum number of days to maturity.

Similar observations on advancement of flowering and harvest times were also reported by Pawar et al. (2003) and Narayanareddy and Biradarpatil (2012) in sunflower, Pothalkar (2007) in pigeonpea, Manjunatha (2007) and Sujatha (2014) in chickpea.

\section{Chlorophyll content of leaves}

The chlorophyll content of leaves gradually decreased towards harvesting stage in green gram. The treatment $T_{11}$ registered significantly highest values of chlorophyll content of leaves-SPAD values (13.32, 14.80 and 14.06) over absolute control $\left(T_{16}\right)(9.30,10.47$ and 9.88$)$ and remained at par with $\mathrm{T}_{13}$ (13.22, 14.68 and 13.95), $\mathrm{T}_{15}(12.85,14.43$ and 13.64), $\mathrm{T}_{12}\left(12.68,14.32\right.$ and 13.50) and $\mathrm{T}_{14}(12.20,14.00$ and 13.10) during 2016, 2017 and on pooled basis respectively.

From the data it is clear that continuous increase in chlorophyll content was noted up to 60 DAS, thereafter it decreased during both the seasons at senescence stage. The agrochemicals and growth substances such as $\mathrm{CaCl}_{2}$, Cycocel and NAA had a positive effect on cell division and cell elongation leading to enhanced leaf expansion, leaf area and thereby chlorophyll content also. The increase in chlorophyll content due to growth regulators and agrochemical may be attributed to decreased chlorophyll degradation and increased chlorophyll synthesis. These results are in accordance with Jayakumar and Thangaraj (1998), Shinde and Jadhav (1995), Dashora and Jain (1994), 


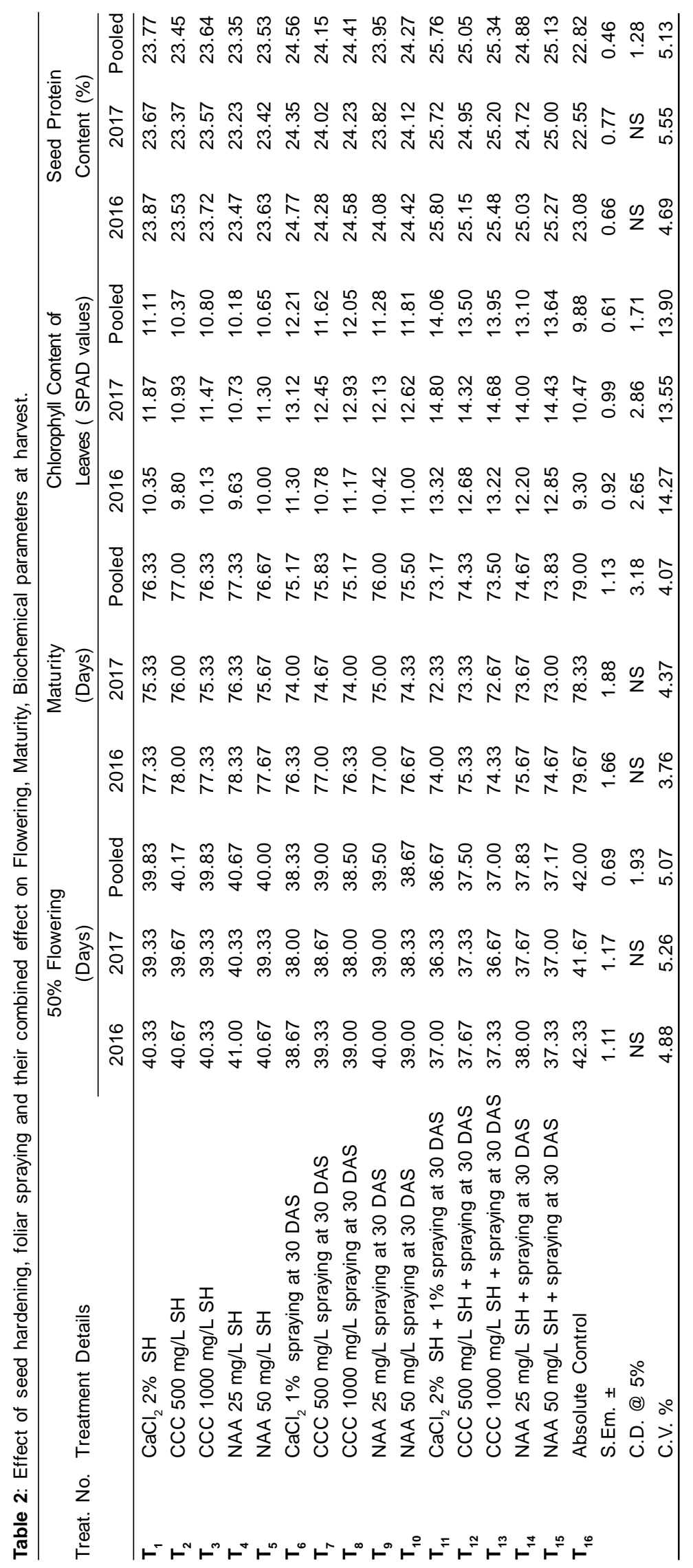


Pothalkar (2007) and Kinjal (2017) in groundnut, cowpea, soybean, pigeon pea and blackgram respectively. In the present investigation, the chlorophyll content showed a positive correlation with grain yield indicating its importance in yield determination.

\section{Seed Protein content (\%)}

The data presented in Table 2 indicated that even though, the statistically non significant differences observed for the seed protein content during both the years but protein content was improved due to the different treatments. The two years pooled data revealed that the seed protein content recorded maximum $(25.76 \%)$ in the treatment $\mathrm{T}_{11}$ and it remained at par with the treatments $\mathrm{T}_{13}(25.34 \%), \mathrm{T}_{15}$ (25.13\%), $\mathrm{T}_{12}(25.05 \%), \mathrm{T}_{14}(24.88 \%)$ and $\mathrm{T}_{6}(24.56 \%)$ in pooled. While, the untreated absolute control treatment $\left(T_{16}\right)$ recorded significantly lowest $(22.82 \%)$ seed protein content.

From the above results, it is clear that there was increase in seed protein content in all the treatments like seed hardening, foliar spraying singly or their combined effect as compared to control. Similarly, the higher seed protein content was reported by Sujatha (2014) in chickpea. Avijit and Misra, (1987) in wheat, Doijode (1975) in garden peas, Bora and Sarma (2005) in pea. Shukla et al. (2018) in chickpea and Kumar et al. (2015) in field bean and Damor and Patel (2018) in mung bean.

\section{Total Number of pods per plant}

The data regarding total number of pods per plant influenced due to different treatments during both the years and on pooled basis were recorded and analyzed are recorded in Table 3. The significantly highest total number of pods per plant (33.73, 35.67 and 34.70) were recorded by the treatment $\mathrm{T}_{11}$, while lowest observed in absolute control (22.00, 23.33 and 22.67) and remained at par with the treatments $T_{13}(32.80$, 34.93 and 33.87), $\mathrm{T}_{15}\left(32.13,34.47\right.$ and 33.30), $\mathrm{T}_{12}$ (31.60, 33.67 and 32.63) and $T_{14}(31.00,33.07$ and 32.03) during 2016, 2017 and in pooled, respectively.

\section{Pod Length}

The significantly highest pod length (8.45) was recorded in the treatment $\mathrm{CaCl}_{2} 2 \%$ seed hardening $+1 \%$ spraying at 30 DAS $\left(T_{11}\right)$ in pooled analysis. The treatment $T_{11}$ was also remained at par with the treatments $T_{13}(8.40), T_{15}(8.33), T_{12}$ (8.03) and $T_{14}$ (7.98). The treatment untreated absolute control $\left(T_{16}\right)$ recorded significantly the lowest pod length (7.10).

\section{Number of seeds per pod}

The treatment $T_{11}$ recorded significantly higher number of seeds per pod (11.93) on pooled basis and remained at par with the treatments $T_{13}(11.83), T_{15}$ (11.57), $T_{12}$ (11.43), $T_{14}$ (11.33), $T_{6}(11.08)$ and $T_{8}(11.00)$. While, the treatment absolute control $\left(T_{16}\right)$ recorded significantly lowest (9.73) number of seeds per pod.

\section{Test weight (g)}

The treatment $\mathrm{CaCl}_{2} 2 \%$ seed hardening $+1 \%$ spraying at 30 DAS $\left(T_{11}\right)$ recorded significantly maximum $(53.80 \mathrm{~g})$ thousand seeds weight in pooled analysis and remained at par with the treatments viz., $\mathrm{T}_{13}, \mathrm{~T}_{15}, \mathrm{~T}_{12}, \mathrm{~T}_{14}, \mathrm{~T}_{6}, \mathrm{~T}_{8}, \mathrm{~T}_{10}, \mathrm{~T}_{7}$ and $T_{9}$. Whereas, the treatment of absolute control $\left(T_{16}\right)$ recorded significantly the minimum $(49.27 \mathrm{~g})$ thousand seed weight.

\section{Seed yield per plant (g plant $\left.{ }^{-1}\right)$}

The treatment $\mathrm{CaCl}_{2} 2 \%$ seed hardening $+1 \%$ spraying at 30 DAS $\left(T_{11}\right)$ recorded significantly higher values of seed yield per plant $(13.07,14.20$ and $13.63 \mathrm{~g})$ and remained at par with $\mathrm{T}_{13}(12.60,13.93$ and $13.27 \mathrm{~g}), \mathrm{T}_{15}(12.47,13.60$ and $13.03 \mathrm{~g})$ and $T_{12}(12.13,13.27$ and $12.70 \mathrm{~g})$ during 2016, 2017 and on pooled basis, respectively. Whereas, the treatment of absolute control $\left(T_{16}\right)$ recorded significantly the lowest seed yield per plant (8.07, 9.40 and $8.73 \mathrm{~g}$, respectively).

\section{Seed yield $\left(\mathrm{kg} \mathrm{ha}^{-1}\right)$}

The significantly highest seed yield per hectare (949, 1006 and $978 \mathrm{~kg} \mathrm{ha}^{-1}$ ) was recorded by the treatment $\mathrm{T}_{11}$ while significantly the lowest was observed in the absolute control $\left(639,679\right.$ and $\left.659 \mathrm{~kg} \mathrm{ha}^{-1}\right)$ during 2016, 2017 and in pooled analysis, respectively and remained at par with the treatments $\mathrm{T}_{13}\left(922,964\right.$ and $\left.943 \mathrm{~kg} \mathrm{ha}^{-1}\right)$ and $\mathrm{T}_{15}(893,917$ and $\left.905 \mathrm{~kg} \mathrm{ha}^{-1}\right)$.

\section{Harvest Index (\%)}

The treatment $\mathrm{CaCl}_{2} 2 \%$ seed hardening $+1 \%$ spraying at 30 DAS $\left(T_{11}\right)$ recorded significantly highest harvest index $(30.15 \%)$ in pooled analysis and remained at par with the treatments $\mathrm{T}_{13}(30.01 \%), \mathrm{T}_{15}(29.84 \%), \mathrm{T}_{12}(29.49 \%), \mathrm{T}_{14}$ (29.27\%), $\mathrm{T}_{6}(28.80 \%), \mathrm{T}_{8}(28.66), \mathrm{T}_{10}(28.35 \%)$ and $\mathrm{T}_{7}$ (28.34\%). While, the treatment of absolute control $\left(T_{16}\right)$ recorded significantly the lowest $(26.84 \%)$ harvest index.

Grain yield is the manifestation of morphological, physiological, biochemical, biophysical and growth parameters. Improvement in yield according to Humphries (1979) could happen in two ways i.e., by adopting the existing varieties to grow better in their environment or by altering the relative proportion of different plant parts so as to increase the yield of economically important parts. The influence of plant growth regulators and seed hardening chemicals significantly increased the seed yield.

In the present investigation, it is observed that the number of pods per plant, pod length, seed yield, number of seeds per pod, 1000 - seed weight increased due to seed hardening or foliar spraying alone and/or in combination of both by agrochemical $\mathrm{CaCl}_{2}$ and growth regulators NAA and Cycocel.

The present study also revealed that increase in seed yield was significantly higher in seed hardening + spraying with $\mathrm{CaCl}_{2}$ (2\% seed hardening and $1 \%$ spraying) followed by Cycocel $1000 \mathrm{mg} / \mathrm{L}$ and NAA $50 \mathrm{mg} / \mathrm{L}$. This could probably be due to beneficial effects of agrochemical and plant growth regulator treatments which help in enhancement of photosynthesis and nitrogen metabolism which are the major physiological process influencing plant growth and development. The treatments of $\mathrm{CaCl}_{2}$ was significantly superior as compared to other treatments in enhancing the plant height, days to flowering, chlorophyll content, number 


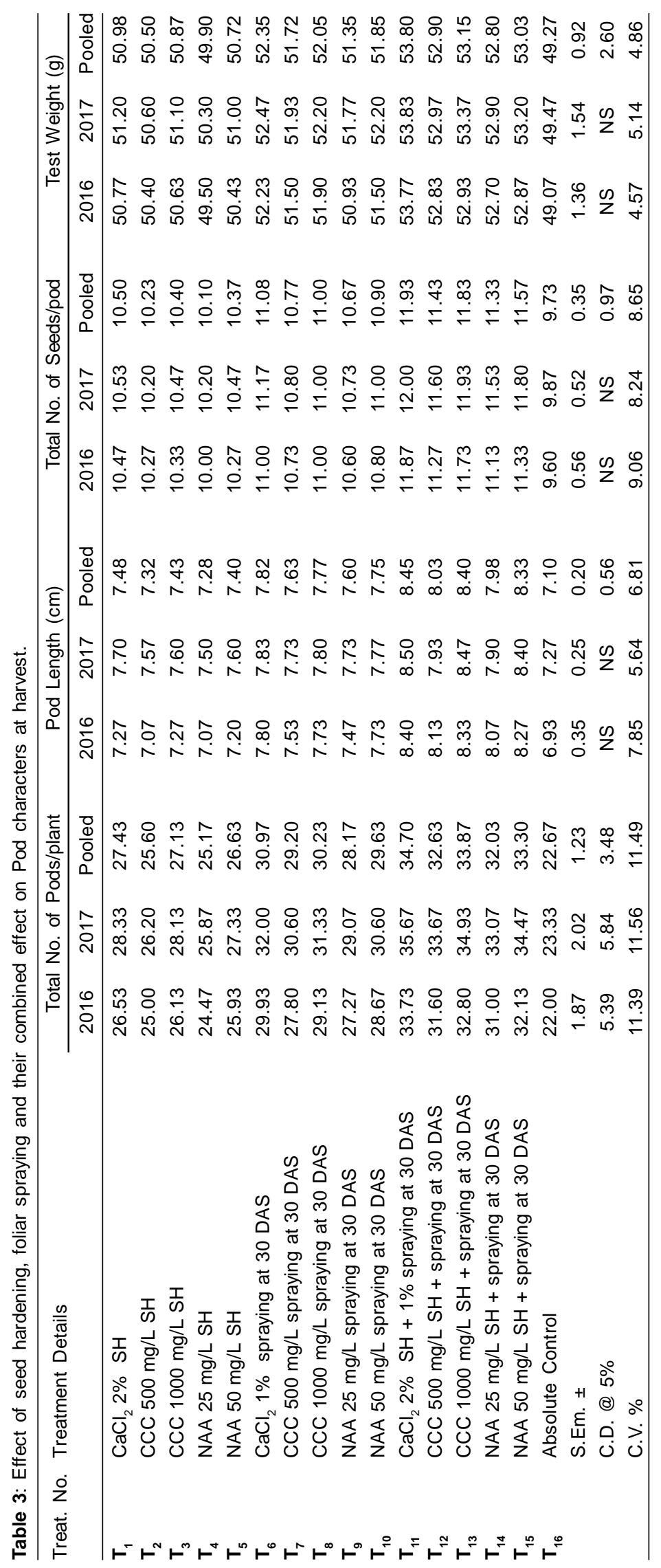




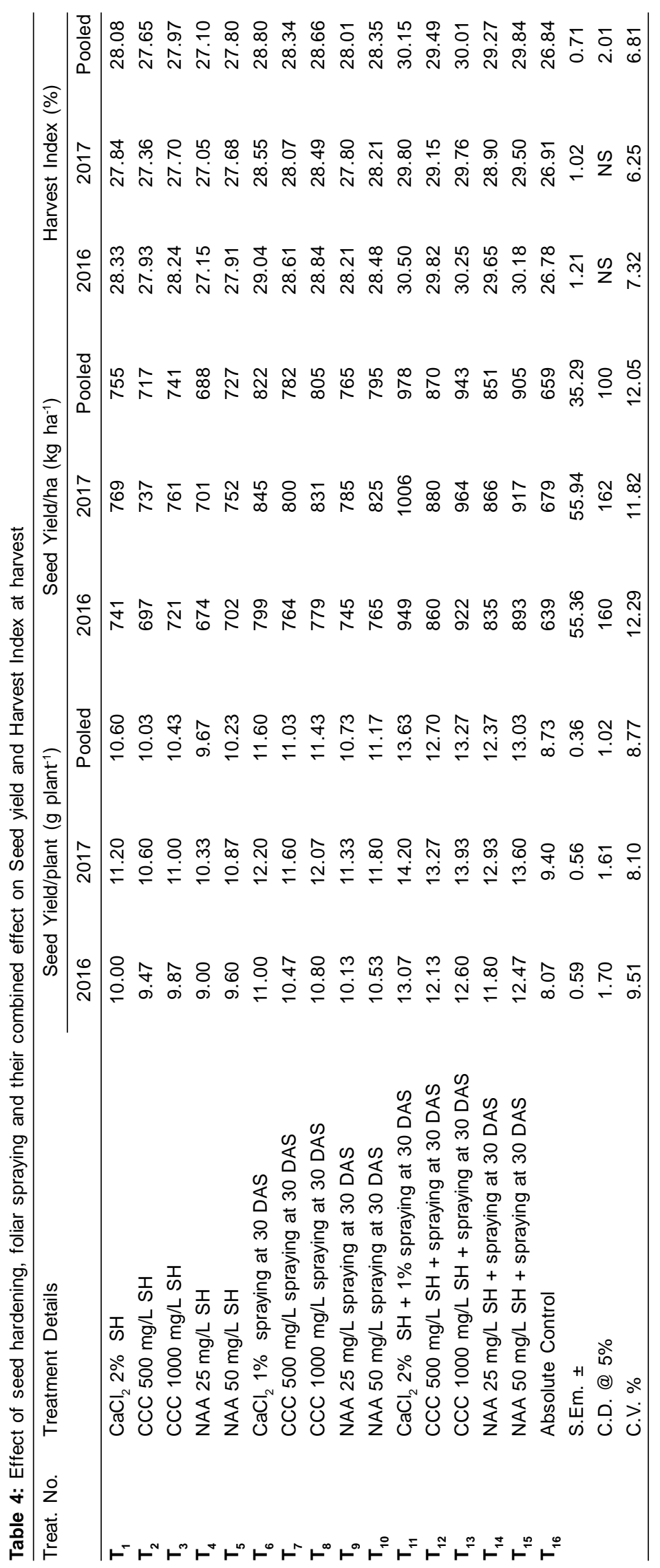


of seeds per plant, 1000-seed weight and thereby seed yield. The increase in the higher yield may be due to better carbon assimilation, better accumulation of carbohydrates and reduced respiration in plants. These results are in agreement with the findings of Mahabir singh and Rajodia (1989) in soybean, Singh and Dohare (1964), Das and Prusty (1982) and Pothalkar (2007) in pigeon pea. The present studies also indicated that growth regulators were very effective in increasing yield and yield attributes as compared to control.

The present study also indicated that seed hardening + spraying, only foliar spraying and only seed hardening treatments with $\mathrm{CaCl}_{2}, \mathrm{CCC}$ and NAA significantly increased the number of pods per plant, seed yield per plant, 1000seed weight and harvest index, which are most important yield determining components in green gram. The increase in seed yield with respect to above treatments was probably due to maximum water absorbing capacity of seeds, more intense photosynthetic activity and more tissue hydration and thereby enabling the plant to resist soil moisture stress more efficiently. This is in conformity with the findings of Mehrotra et al., 1970 in okra, Arjunan and Srinivasan, 1989 in groundnut, Masood Ali (1985) in chickpea, Sen and Misra (1987) in wheat, Patil (1987) in sorghum, Shinde et al., (1991) in cowpea, Singh et al., (1991) in chickpea, Bora and Sarma (2005) in pea, Shinde and Jadhav (1995) in pigeonpea, Amaregouda et al., (1994) in wheat, Jirali (2001) in turmeric and Prabhu (2000) in black gram.

\section{CONCLUSION}

Based on the above results, it is inferred that the yield potential in green gram can be improved by using plant growth regulators and agrochemical. The results also indicated a significant improvement in morpho-physiological traits, growth parameters, biochemical constituents and thereby yield due to the application of PGR's and agrochemical. Among the different treatments, seed hardening with $2 \% \mathrm{CaCl}_{2}+1 \%$ foliar spraying at $30 \mathrm{DAS}$ treatment significantly improved the most of morphophysiological parameters and thereby yield in green gram followed by the seed hardening treatments of Cycocel 1000 $\mathrm{mg} / \mathrm{L}+$ foliar spraying at $30 \mathrm{DAS}$ and seed hardening with NAA $50 \mathrm{mg} / \mathrm{L}+$ foliar spraying at 30 DAS.

\section{REFERENCES}

Amaregouda, A., Chetti, M.B. and Manjunath, S. (1994). Physiological basis of yield variation due to application of different chemicals in wheat. Annals Plant Physiology. 8: 24-28.

Amarjeet Singh, Thounaojam. (2014). Influence of planting materials and plant growth bio-regulants on growth, yield and quality of turmeric (Curcuma longa L.). Ph. D. Thesis, Anand Agricultural University, Anand, Gujarat, India.

Ananthi, K. and Mallika, Vanangamudi. (2014). Foliar spray of humic acid with growth regulators in nutrient content and yield of greengram [Vigna radiata (L.) Wilczek]. Legume Research. 37(4): 359-62.

AOAC. (1990). Association of Official Analytical Chemist, official method of analysis, $15^{\text {th }}($ Edn). Washington DC.
Arjun Sharma, Potdar, M.P., Pujari, B.T., Dharmaraj, P.S. and Sharma, A. (2003). Studies on response of pigeon pea to canopy modification and plant geometry. Karnataka Journal of Agricultural Science. 16: 1-3.

Arjunan, N. and Srinivasan, P.S. (1989). Pre-sowing seed hardening for drought tolerance in groundnut (Arachis hypogaea L.). Madras Agricultural Journal. 76(9): 523-26.

Avijit, S. (1983). Growth and dry matter accumulation in wheat under rainfed condition as affected by pre-sowing seed hardening. Madras Agriculture Journal. 70(4): 264-65.

Avijit, S. and Misra, N.M. (1987). Effect of pre-sowing seed treatments and phosphate doses on yield, quality and nutrient uptake of wheat. Agricultural Science Digest. 7: 213-16.

Bewley, J.D. and Black, M. (1982). Physiology and biochemistry of seeds in relation to germination. Vol. 2. Springer, Berlin, p375.

Bora, R.K. and Sarma, C.M. (2005). Effect of growth regulators on growth and yield of pea. Advance Plant Science. 18(11): 835-39.

Bozeuk, S. (1981). Effect of kinetin and salinity on germination of tomato, barley and cotton seeds. Annals of Botany. 48: 81-84.

Damor, P.R. and Patel, A.D. (2018). Effect of source manipulation, plant growth regulators and chemical on biochemical parameters in green gram [Vigna radiata (L.) Wilckzek] cv. GAM-5. International Journal of Chemical Studies. 6(4): 2089-2091.

Das, P.C. and Prusty, S.B. (1982). Growth regulators effect on seed treated brinjal plant in relation to vegetative development. Indian Journal of Horticulture. 29: 234-35.

Dighe, R.S., Thakare, J.T. and Hall, S.B. (1983). Effect of 2-chloroethyl trimethyl ammonium chloride on growth and yield of wheat. Punjabrao Krishi Vidyapeet Research Journal. 7: 12-15.

Dashora, L.D. and Jain, P.M. (1994). Effect of growth regulators and phosphorus levels on growth and yield of soybean. Madras Agricultural Journal. 81: 235-37.

Doijode, S.D. (1975). Effect of growth regulators on growth and yield of garden pea (Pisum sativum var. hortense L.) M.Sc. (Agri.) Thesis, University of Agricultural Sciences, Bangalore, Karnataka, India.

Garai, A.K. and Datta, J.K. (2003). Effect of phosphorus sources and cycocel spray on green gram (Vigna radiate L.). Legume Research. 26 (1): 15-19.

Ginzo, H.D., Carcellas, M.S. and Fonseca, E. (1977). CCC (2chloroethyl trimethyl ammonium chloride) and the regulation of plant water status in wheat (Triticum aestivum L.). Phyton Argentina. 35: 82-92.

Humphries. (1979). Response of crop plants to growth regulators. Monograph 31. Rothamsted Experiemntal Station, p33.

Jain, V.K. (2013). Fundamentals of Plant Physiology (Revised edition). S. Chand publication. Pp 458.

Jayakumar, P. and Thangaraj, M. (1998). Physiological and biochemical effects of mepiquat chloride in groundnut (Arachis hypogaea). Madras Agricultral Journal. 85: 23-26.

Jirali, D.I. (2001). Physiological investigation in turmeric (Curcuma longa L.). Ph. D. Thesis, University of Agricultural Sciences, Dharwad, Karnataka, India.

Josana, A. Samal (2015). Influence of seed hardening on the growth 
and yield of chickpea (Cicer arietinum L.). M. Sc. (Agri.) Thesis, Anand Agricultural University, Anand, Gujarat, India.

JunMin, H., Xiaoping, S. and Jian, Z. (2000). Mitigative effects of hydration-dehydration treatments on salt stress induced injury to tomato seed germination. Deta. Horticulture Sinica. 27: 123-26.

Kinjal, R. Prajapati. (2017). Effect of seed hardening on germination, growth and yield of black gram (Vigna mungo L.). M. Sc. (Agri.) Thesis, Anand Agricultural University, Anand, Gujarat, India.

Kumar, S.E., Channaveerswami, A.S., Naik, V.R. and Krishna, A. (2015). Effect of nipping and hormonal spray on seed yield and quality of field bean genotypes. 8th National Seed Congress, Hyderabad. 223-224.

Mahabir, Singh and Rajodia, R.B. (1989). Effect of gibberellic acid on growth and yield attributes of radish varieties. Indian Journal of Plant Physiology. pp. 167-71.

Manjunath, B.L. (2007). Physiological basis of seed hardening in chickpea (Cicer arietinum. L). M. Sc. (Agri.) Thesis, University of Agricultural Sciences, Dharwad, Karnataka, India.

Manjunath, B.L. and Dhanoji, M. M. (2011). Effect of seed hardening with chemicals on drought tolerance traits and yield in chickpea. (Cicer arietinum. L). Journal of Agricultural Sciences. 3(3): 186-89.

Masood, Ali. (1985). Effect of pre soaking seed treatment, foliar nutrition and planting pattern on productivity and water use in chickpea under rainfed conditions. Legume Research. 8(1): 7-11.

Mehrotra, O.N., Garg, R.C. and lqbal, Singh. (1970). Effect of CCC (2-chloro methyl trimethyl ammonium chloride) on growth and yield of okra (Abelmoschus esculentus L. moench). Indian Journal of Plant Physiology. 13: 173-79.

Narayanareddy, A.B. and Biradarapatil, N.K. (2012). Effect of presowing invigouration seed treatments on seed quality and crop establishment in sunflower hybrid KBSH-1. Karnataka Journal of Agricultural Science. 25(1): 43-46.

Patil. (1987). Physilogical factors influencing growth and yield of rabi sorghum (Sorghum bicolar L.) genotypes under rainfed conditions. M.Sc. (Agri.) Thesis, University of Agricultural Science, Dharwad, Karnataka, India.

Patil, S.S., Bhadane, R.S., Patil, T.R. and Patil, A.J. (2007). Dry matter accumulation and its distribution in various plant parts in drought resistant groundnut genotypes. PKV Research Journal. 31(2): 192-196.

Pawar, K.N., Sajjan, A. and Prakash, B.G. (2003). Influence of seed hardening on growth and yield of sunflower. Karnataka Journal of Agricultural Science. 16: 539-41.

Pothalkar, S.M. (2007). Physiological investigations on drought tolerance in pigeonpea (Cajanus cajan L.). Ph. D. Thesis, University of Agricultural Sciences, Dharwad, Karnataka, India.

Prabhu, D. (2000). Influence of plant growth regulators and micronutrients in blackgram (Vigna mungo). M. Sc. (Agri.) Thesis, University of Agricultural Sciences, Dharwad, Karnataka, India.

Prakash, M., Narayanan, G., Sunil, B. and Kamaraj, A. (2013). Effect of seed hardening and pelleting on seed quality and physiology of rice in aerobic condition. Agriculture Science Digest. 33(3): 172-77.
Sankar Ganesh, K., Sundaramoorthy, P., Baskaran, L., Rajesh, M. and Rajasekaran, S. (2013). Effect of pre-sowing hardening treatments using various plant growth hormones on two varieties of green gram germination and seedling establishment. International Journal of Modern Biology and Medicine. 3(2): 78-87.

Sen and Misra, N.M. (1987). Effect of pre-sowing seed treatments and phosphate doses on yield, quality and nutrient uptake of wheat. Agricultural Science Digest. 7: 213-16.

Shinde, A.K. and Jadhav, B.B. (1995). Influence of NAA, ethrel and $\mathrm{KNO}_{3}$ on leaf physiology and yield of cowpea. Annals of Plant Physiology. 9: 43-46.

Shinde, A.K., Jamadagni, B.M. and Birari. S.P. (1991). Effect of foliar spray of growth regulators and $\mathrm{KNO}_{3}$ on growth and yield of cowpea [Vigna unguculata (L.) walp] variety VCM-8. Indian Journal of Plant Physiology. 34: 392-95.

Singh, K., Afria, B.S. and Kakralya, B.L. (1991). Seed and protein yield of macrosperma chickpea in response to treatment with growth substances under field conditions. Indian Journal of Plant Physiology. 34(2): 137-42.

Singh, K. and Dohare, S.R. (1964). An experiment was conducted with a view to evaluating the potentiality of pre-sowing treatment of NAA on white long radish. Punjab Horticulture Journal. 4: 160-64.

Shukla, A.K., Singh, R.K., Pandey, A.K., Gautam, M.K., Vishen, G.S. (2018). Effect of growth regulators and nipping on biochemical traits and yield attributes of chickpea (Cicer arietinum L.). International Journal of Chemical Studies. 6(1): 438-442.

Sujatha M. (2014). Studies on effect of seed hardening, nipping and foliar spray of cycocel on growth, yield and quality of chickpea (Cicer arietinum L.). M. Sc. (Agri.) Thesis, University of Agricultural Sciences, Dharwad, Karnataka, India.

Sujatha, M., Uppar, D.S., Deshpande, V.K. and Nawalagatti, C.M. (2017). Effect of seed hardening nipping and foliar spray of cycocel on growth, yield and quality of chickpea (Cicer arientinum L.). Environment and Ecology. 35 (2): 703-07.

Sunil, Jadhav. (2016). Enfluence of plant growth regulators and micronutrients on growth and seed yield of black gram. M. Sc. (Agri.) Thesis, University of Agricultural Sciences, Bengaluru, Karnataka, India.

Thirumalaiswamy, K. and Sakharam Rao, J. (1977). Effect of pretreatment of seeds and water stress on net assimilation rate, relative growth rate and leaf area of Pennisetum typhoids Stapf and Hubb. Madras Agricultural Journal. 64: 270-72.

Upadhyay, R.G., Negi, P.S., Yadav, S.K. and Anil, K. (2016). Effect of growth regulators on growth parameters, biochemical constituents and yield of soybean (Glycine max L.) during changing scenario of climate under mid hill conditions of North Western Himalayas. International Journal of Tropical Agriculture. 34(4): 1073-78.

Varma, C.B., Lallu and Yadav, R.S. (2004). Effect of boron and zinc application on growth and yield of pigeon pea. Indian Journal of Pulses Research. 17(2): 149-51.

Vikram Singh, S.K. Sharma, S.K. Thakral and M.K. Sharma. (2019). Effect of phosphorus on the performance of greengram (Vigna radiata $\mathrm{L}$ ) varieties during summer. Legume Research. 42(2): 247-249. 